\title{
スーパーコンピュータによる大規模構造解析
}

\section{三好 俊郎}

Toshro MIYOSHI

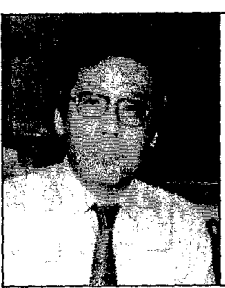

-1946年 3 月生京机

一有限要素法, 破㙲力学に関寸当研究定実施。

現在, 計算力学に従事

- 正員, 東京大学工学部（ 1113 東京都文京 区本郷 7-3-1)

\section{1.はじめに}

世界最初のスーパーコンピュータといわれる CDC 6600 (1964，約 1 MFLOPS(注 1)) が生まれ てから 25 年の年月が経過し(1), 最高速度のスー パーコンピュータはついに GFLOPS の演算速度 を有する時代を迎えた。

スーパーコンピュータの普及により, 有限要素 法 (FEM), 境界要素法 (BEM), 差分法 (FDM) などの計算力学の分野は新しい時代に向 けてダイナミックな変貌を遂げつつある。これま で不可能と考えられていた精密・大規模な数値シ ミュレーションが可能となり，未踏であった分野 の開拓が始まっている.

本展望においては，有限要素法による構造解析 を対象とし，スーパーコンピュータによる大規模 解析システムについて述べる。

\section{2. スーパーコンピューティング}

スーパーコンピュータを用いて高速・大規模な 科学技術計算を行うことをスーパーコンピューテ

(注 1) MFLOPS = Million Floating-point Operations Per Second の略. 1秒間に百万回（106回）の浮動小数点 演算を行う速さをlとする処理速度の単位. GFLOPS $=10^{3}$ MFLOPS.

日本機械学会誌

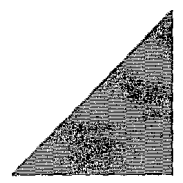

イングという。ここでは，スーパーコンピュータ のハードウェアおよびソフトウェアについて概略 を述べる。

現在，スーパーコンピュータの多くはベクトル パイプライン方式を採用して招り，図１に示すよ うにベクトル演算器によるべクトル処理によって 高速性を達成している(2), これに対し, 従来のは ん用コンピュータの演算方式はスカラー処理とよ ぼれている。プログラムの全演算に対するベクト ル処理される演算の比率をべクトル化率という。 また，ベクトル処理方式とスカラー処理方式によ る計算時間の比を加速率といい, ともにス一パー コンピュータ用プログラムの性能を評価する指標 として用いられる(注2)。一般に, ベクトル化率 が $90 \%$ を超えてはじめて十分な高速性が達せら れるといわれている。

しかし，従来のはん用コンピュータ用に作成さ れたプログラムをそのままスーパーコンピュータ のコンパイラによる自動ベクトル化に頼って実行 したのでは，90\%以上の高いべクトル化率を得 るのは困難である。八ードウェアの性能を十分に 活かすような計算技法，ソフトウェアの開発が必 要とされる。

\section{3. 計算技法}

$3 \cdot 1$ 剛性方程式の解法 スーパーコンピュ 一タを用いて有限要素解析を行う利点は高速性と 大規模性の二点にある。筆者らの経験では，有限

(注 2) スーパーコンピュータは, ベクトル演算器によるべク トル処理方式で計算をするのが普通であるが，はん用 コンピュータのようなスカラー処理方式で計算するこ ともできる.

1989 年 6 月 
要素法による構造解析においては計算時間の約 $70 \%$ 程度が剛性方程式の解法に費やされており， 剛性方程式の解法は有限要素解析のキーポイント である。そこで，本章では高速計算㧍よび大規模 計算に適した剛性方程式の解法（ソルバー）で市 るスカイライン法, ICCG 法について述心゙る。

$3 \cdot 2$ パラレルスカイライン法 スカイライ ン法は消去法の一つであり，剛性マトリックスを

DO $10 \quad I=1,10$

$10 \mathrm{~A}(\mathrm{I})=\mathrm{B}(\mathrm{I})+\mathrm{C}(\mathrm{I})$

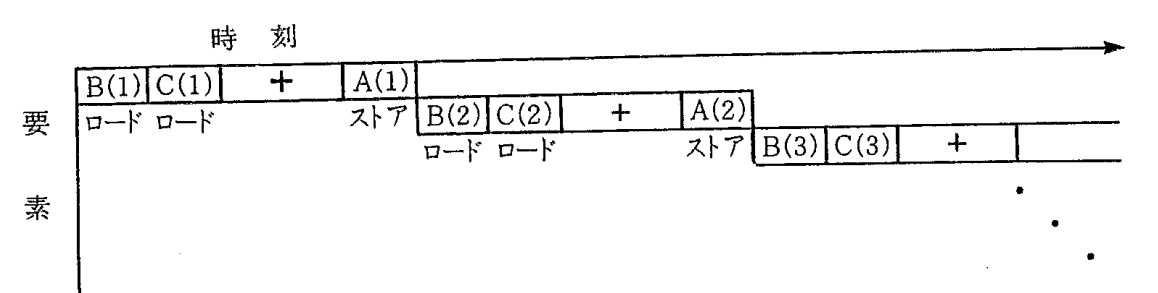

スカラー処理

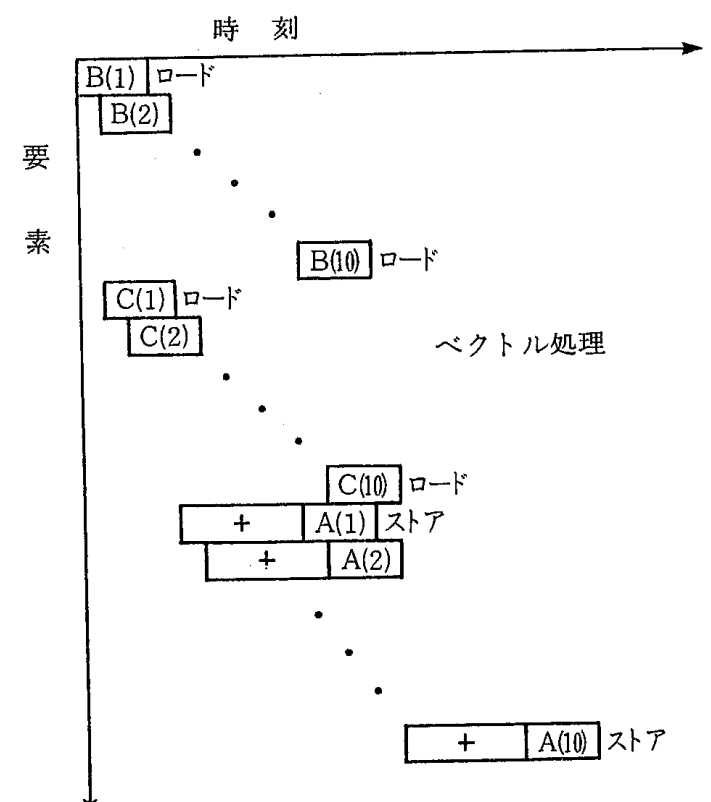

図 1 スカラー処理とベクトル処理(2)

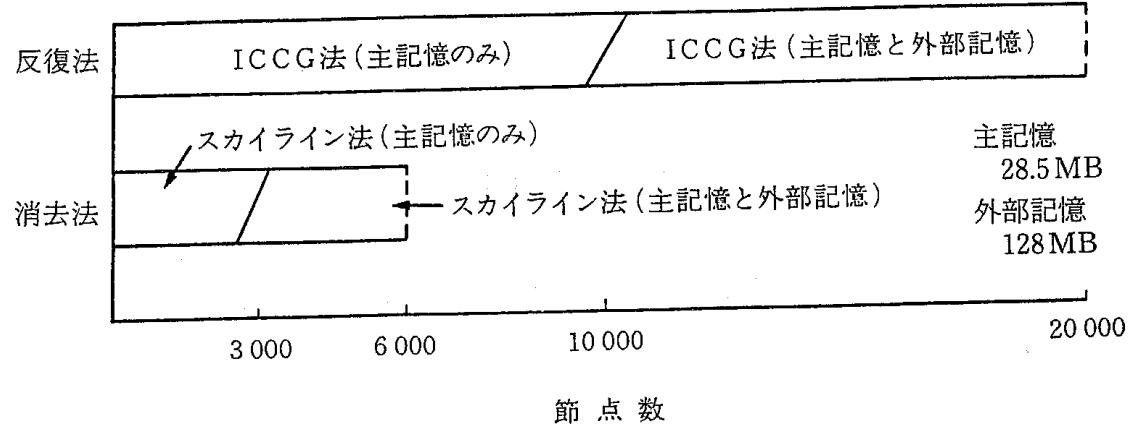

図 2 ソルバーの適用範囲（三次元構造解析の場合）

Jour. JSME
改訂コレスキー分解して解く方法である。 スカイ ライン法の計算主要部はスーパーコンピュータが 得意とする内積計算であり，高い加速率が得られ る.

スカイライン法を改良し, 複数のベタトル演算 器老並列に動作させ，より高速性定得るために開 発されたソルバーがパラレルスカイライン法(3)で ある. パラレルスカイライン法は, 改訂コレスキ 一分解に扔いて 3 行 3 列同時分解 （三次元構造解析の場合）を行う もので方り，高速計算に適した解 法である。

\section{$3 \cdot 3$ 内積形式のスカイライン} 法 スーパーコンピュータの 発展の方向は, 複数の CPU を有 する並列方式のスーパーコンピュ

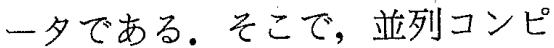
ュータ向きのソルバーとして内積 形式のスカイライン法(4)を紹介す る.

従来のスカイライン法は, 縁ど り法(5)とよばれるアルゴリズムを 用いている。縁どり法の場合，並 列性は明示的ではない。一方，内 積形式のスカイライン法では, 最 内側 DO ループはベクトル処理が 可能であり，さらに一つ外側の DO ループに関して並列化もでき る.したがって, ベクトル化と並 列化の相乗効果による高速化に適 している。また，この場合も前述 のパラレルスカイライン法と同様 に 3 行 3 列同時分解による高速化 が有効である(4).

\subsection{ICCG 法 ICCG 法(6)} は反復法の一つであり，前処理と して剛性マトリックスに不完全コ レスキー分解を施した後, 共役こ う配法を適用する解法である。 ICCG 法は，剛性マトリックスの 非零成分のみを用いて計算を行う ことができるためメモリ効率が良 く，大規模計算に適している. 
図 2 は, 東京大学大型計算機センターにおいて 主記憶 $28.5 \mathrm{MB}$ ，外部記憶 $128 \mathrm{MB}$ を使用できる という環境を想定して作成したソルバーの適用䇭 囲である。ICCG 法を用いることにより約 20000 節点までの大規模解析が可能となる。

$$
3.5 \text { ベンチマークテスト スーパーコンピ }
$$
ュータ用に作成した有限要素解析プログラム FEM 3 D/S $\mathrm{S}^{(3)}$ およびFEM $3 \mathrm{D} / \mathrm{I}^{(6)}$ を用いて各種 スーパーコンピュータおよびはん用コンピュータ によるベンチマークテストを行った結果について 述べる(7). FEM 3 D/S および FEM 3 D/I は， 各々ソルバーとしてパラレルスカイライン法, ICCG 法を使用している。このベンチマークテス 卜は日本機械学会 RC-74「非線形有限要素法の 応用研究分科会」第 4 小委員会スーパーコンピュ ータワーキンググループの活動として行われた。

ベンチマーク問題は図 3 に示す三次元表面き裂 材の一様引張り（190 要素， 970 節点）である.

FEM 3 D/S による計算時間を表 1 に, FEM 3 D/I による計算時間を表 2 に示す．表 1 および表 2 は左半分がスーパーコンピュータ，右半分がは ん用コンピュータによる計算時間である.表 1 の CRAY X-MP/3 は CRAY X-MP/4（4 CPU 構 成の CRAY X-MP) の $3 \mathrm{CPU}$ をいて計算し たことを示している。また，べクトル化率の括弧
内は推定値である。

ベタトル化率はFEM 3 D/S, FEM 3 D/I とも に 90\%以上であり，加速率は3〜15 程度である。 またはん用コンピュータと比較すると最高 100 倍程度の計算速度が得られている。

\section{4. システムインテグレーション}

スーパーコンピュータおよびこれに接続される 端末などを含むコンピュータシステムの有効利用 に関する事柄はシステムインテグレーションとよ ばれている，効率的なスーパーコンピューティン グを実現するためにはシステムインテグレーショ ンに関する研究は不可欠である。

$3 \cdot 5$ 節で示したように, スーパーコンピュータ に対し適切な計算技法, ソフトウェアを用いるこ とにより高速，大規模な有限要素解析が行える。 その結果, 膨大な入力データの作成（プリプロセ ス）および計算結果の処理（ポストプロセス）を 効率良く行うことが重要な問題として浮上してく る.

図 4 にスーパーコンピュータによる大規模構造 解析システム ${ }^{(8)}$ の例を示す. 本システムでは, 有 限要素解析にスーパーコンピュータ HITAC S820/80を，プリ・ポストプロセスにEWS を用い

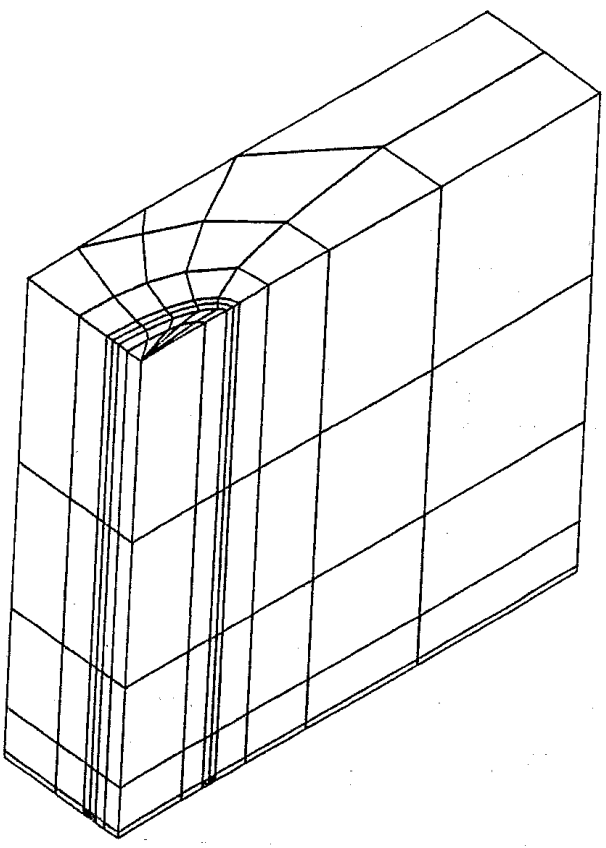

(b) 要素分割 (190 要素, 970 節点)
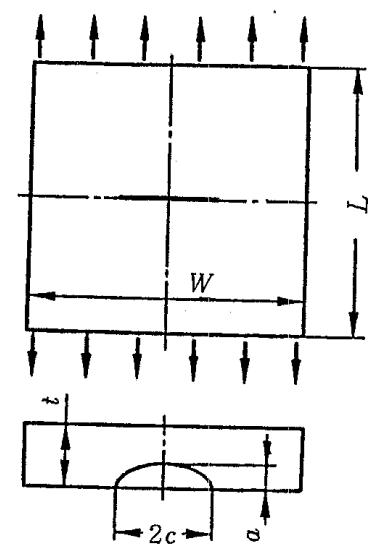

$a / t=0.25 \quad 2 c / W=0.2$

$a / c=0.33 \quad W=L=52.5 \mathrm{~mm}$

(a) 三次元表面き裂材の形状

図 3 ベンチマーク問題（三次元表面き裂材の引張り） 
表 1 パラレルスカイライン法 (FEM $3 \mathrm{D} / \mathrm{S})$ による計算㭙間

\begin{tabular}{|c|c|c|c|c|c|c|}
\hline 機 種 & コンパイラ & 計算時間(s) & ベタトル化率 & 機 種 & コンパイラ & 計算時間(s) \\
\hline CRAY X-MP/1 & CFI77 Rel.1.3 & 8.52 & $(92)$ & FACOM M-380Q & FORTRAN77 & 174.45 \\
\hline CRAY $\mathrm{X}-\mathrm{MP} / 3$ & CFT77 Rel.1.3 & 3.34 & $(92)$ & FACOM M-380Q & VS FORTRAN & 203.12 \\
\hline FACOM VP-50 & $\begin{array}{c}\text { FORTRAN } \\
77 / \mathrm{VP} \\
\end{array}$ & 15.02 & 96.09 & IBM $3081 \mathrm{~K}$ & FORTRAN77 & 311.41 \\
\hline FACOM VP-100 & $\begin{array}{c}\text { VP COMP } \\
\text { V10/L20 } \\
\end{array}$ & 10.11 & 93.50 & IBM $3081 \mathrm{~K}$ & VS FORTRAN & 337.58 \\
\hline \multirow[t]{3}{*}{ HITAC S $-810 / 20$} & $\begin{array}{l}\text { FORTRAN } \\
77 / \mathrm{HAP}\end{array}$ & 7.30 & 96.60 & IBM $3090-200$ & VS FORTRAN & 101.68 \\
\hline & & & & HITAC M-682H & OFORT77 & 61.59 \\
\hline & & & & $\begin{array}{l}\text { HITAC M-682H } \\
\text { (IAP) }\end{array}$ & OFORT77 & 25.06 \\
\hline
\end{tabular}

表 2 ICCG 法（FEM 3 D/I）による計算時間

\begin{tabular}{c|c|c|c||c|c|c}
\hline \hline 機 種 & コンパイラ & 計算時間(s) & ベクトル化率 & 機 種 & コンパイラ & 計算時間 $(\mathrm{s})$ \\
\hline CRAY X-MP/1 & CFT77 Rel.1.3 & 14.09 & & DEC MICRO VAX-II & FORTRAN V4.6 & 8603.19 \\
\hline FACOM VP-50 & FORTRAN77/VP & 24.26 & 93.22 & FACOM M-380Q & FORTRAN77 & 224.67 \\
\hline FACOM VP-100 & $\begin{array}{c}\text { VP COMP. } \\
\text { V10/L30 }\end{array}$ & 21.40 & 94.40 & FACOM M-380Q & VS FORTRAN & 226.30 \\
\hline HITAC S-810/20 & $\begin{array}{c}\text { FORTRAN } \\
77 / H A P\end{array}$ & 16.27 & & IBM 3081K & FORTRAN77 & 310.16 \\
\hline HITAC S-820/80 & $\begin{array}{c}\text { FORTRAN } \\
\text { 77/HAP }\end{array}$ & 6.75 & & IBM 3081K & VS FORTRAN & 309.06 \\
\hline & & & IBM 3090-200 & VS FORTRAN & 99.83 \\
\hline
\end{tabular}

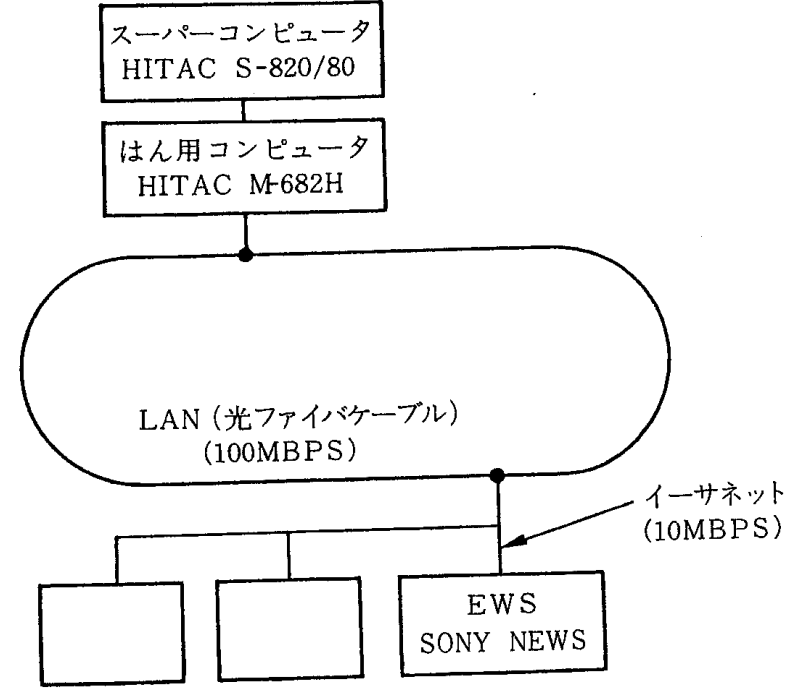

(a) ハードウェア

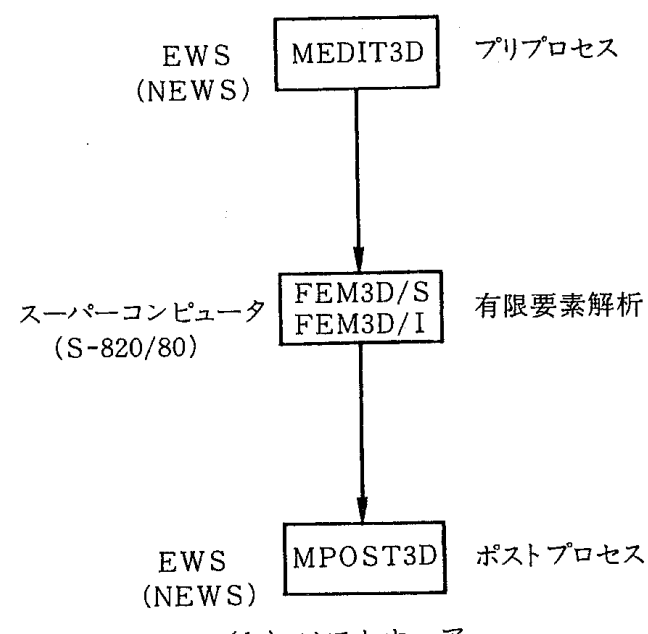

(b) ソフトウェア

図 4 スーパーコンピュータによる大規模構造解析システム 


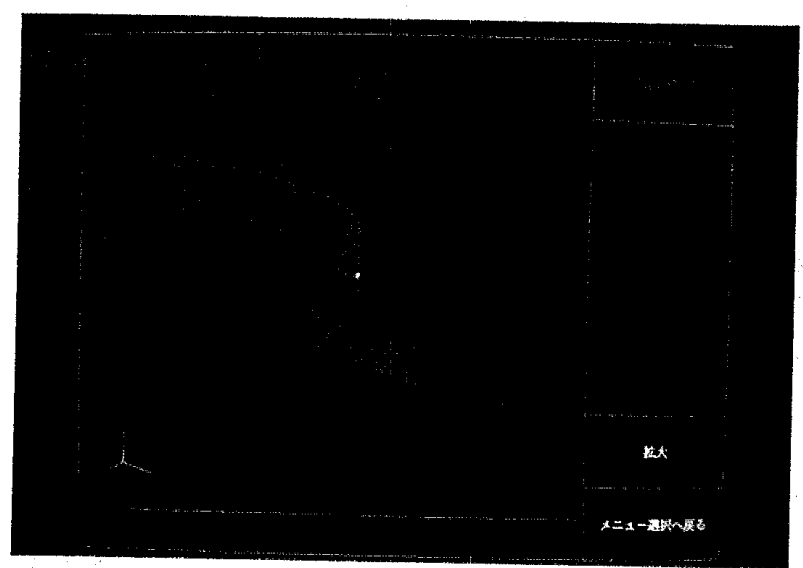

図 5 要素分割図

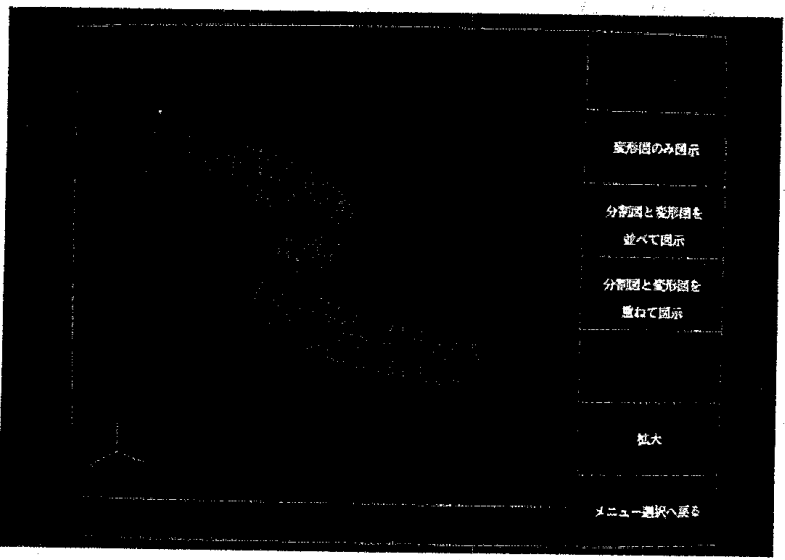

図 6 変形図

ている. EWS はSONY NEWS NWS-830であ る. EWS とスーパーコンピュータは，LAN に より接続されている.

本システムを用いて，軸方向圧縮を受けるクラ ンク材の弾塑性解析を行った。要素数 3456 , 節 点数 17605 の大規模解析である.解析は 4 ステ ージ行い, 計算時間はスーパーコンピュータ HITAC S-810/20で1764sである.ポストプロ セッサを用いて解析結果をカラーグラフィックス 表示した結果を図 5〜7に示す.図 5 は要素分割 図, 図 6 は変形図, 図 7 は応力図である。このよ うに解析結果をビジュアルにとらえることによ り，評価を効率良く行うことが可能となる。

\section{5.おわりに}

スーパーコンピュータによる大規模解析システ ムを実現するためのキーポイントとして，

(1) スーパーコンピュータのハードウェアの特 徵を活かした計算技法とソフトウェア

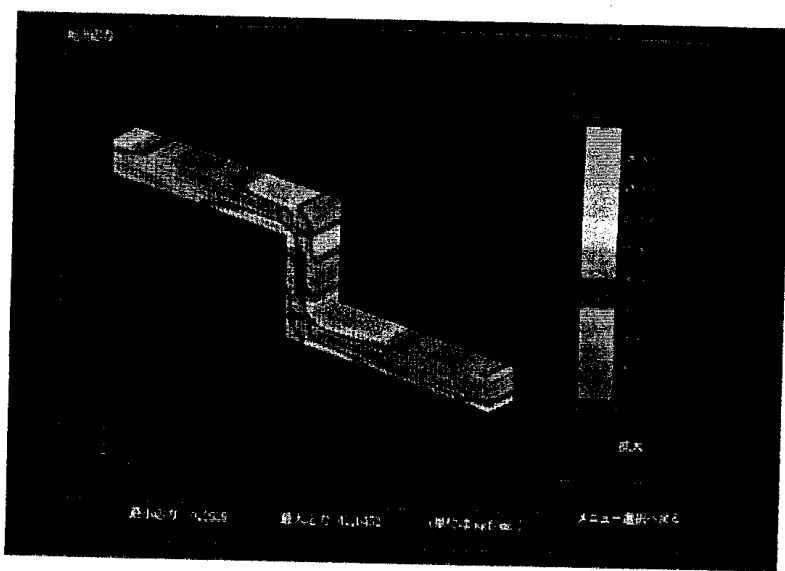

図 7 応力図

(2) システムインテグレーション について述べた。

今後の動向として, Parallel Computing は必 要不可欠な計算技法であろう。複数の CPU を有 する並列方式のスーパーコンピュータとしてはす でに CRAY，ETAなどがある．国産のスーパー コンピュータは単一CPUの性能は非常にすぐれ ているが, 近い将来複数 CPUへの移行が予想さ れる。複数 CPU のスーパーコンピュー夕を効率 的に用いるため, 有限要素法の分野においては内 積形式のスカイライン法などの並列処理アルゴリ ズムの研究は重要な課題である.

一方，本稿においてはふれなかったが演算速度 だけでなく高度なグラフィックス能力を兼ね備え たグラフィックススーパーコンピュータ(9)の登場 は興味深い。これを用いて, 解析結果のアニメー ション化が容易に行えるシステムの開発なども期 待される。

\section{文献}

（1）村田・ほか2名，スーパーコンピュータ，(1985)，3，丸善

（2）加藤・大吉，日本鋼構造協会構造工学に扔ける数值解析法 シンポジウム論文集，9（1985-7)，61.

(3) 三好・吉田，機論，53-486，A (1987)，255.

（4）三好・高野，日本機械学会計算力学講演会講演概要集， No. 890-1 (1989-1), 18.

（5）文献(1)の106ページ.

(6) 三好・ほ加2 名, 機論, 53-492, A (1987)，1607

（7）三好・ほ加2 名，日本機械学会計算力学講演会講演概要 集, No.890-1 (1989-1), 13.

（8）三好・ほか 3 名，日本鋼構造協会構造工学における数值解 析法シンポジウム論文集, 12 (1988-7), 133 .

（9）鹿野，情報処理，29-10，(1988），1117。 